\title{
Gentrification in Porto: floating city users and internationally-driven urban change
}

\author{
Luís Carvalho, Pedro Chamusca, José Fernandes \& Jorge Pinto
}

To cite this article: Luís Carvalho, Pedro Chamusca, José Fernandes \& Jorge Pinto (2019) Gentrification in Porto: floating city users and internationally-driven urban change, Urban Geography, 40:4, 565-572, DOI: 10.1080/02723638.2019.1585139

To link to this article: https://doi.org/10.1080/02723638.2019.1585139

曲 Published online: 27 Feb 2019.

Submit your article to this journal $\sqsubset$

Llll Article views: 538

Q View related articles $₫$

View Crossmark data \lceil

4 Citing articles: 2 View citing articles 진 


\title{
Gentrification in Porto: floating city users and internationally-driven urban change
}

\author{
Luís Carvalho (D) ${ }^{a}$, Pedro Chamusca $\mathbb{D}^{a}$, José Fernandes $\mathbb{D D}^{\mathrm{a}}$ and Jorge Pinto $\mathbb{D}^{\mathrm{b}}$
}

${ }^{a}$ Centre of Studies in Geography and Spatial Planning, University of Porto/CEGOT, Porto, Portugal; ${ }^{b}$ Center of Studies in Geography and Spatial Planning, ISCET- Higher Institute of Business and Tourism/CEGOT, Porto, Portugal

\begin{abstract}
The heightening scale of urban tourism and the fast-growing number of "floating" city users raise new challenges to understand contemporary urban change - namely for internationally open, heritage-rich medium-sized cities. Discussing the case of Porto at a time when the contested notion of gentrification infuses local politics, we highlight the transnational drivers of this process in Portugal's second city. While acknowledging perils and benefits, we argue that more than simply leaving a footprint to be solved with taxation, internationally-driven gentrification may endanger city diversity and identity, raising implications for urban policy and for our understanding of local development as a whole.
\end{abstract}

\section{ARTICLE HISTORY}

Received 13 September 2018

Accepted 2 February 2019

\section{KEYWORDS}

Transnational gentrification; touristification; studentification; retail; holiday rentals

In January 2018, during an interview to a Spanish newspaper, the Mayor of Porto Portugal's second largest city - affirmed that

"[a]ll the drama about tourism is a very boring talk. Porto has always been gentrified by the British, the Germans and the French. (...) Gentrification is a boring idea of a reactionary Left speaking about something that does not exist" (Rui Moreira, in La Voz de Galicia, 21 January 2018, authors' translation).

This statement may have multiple interpretations but, among others, it shows that the gentrification debate has gained a relevant place in city politics, in particular in connection to a recent city centre revival and the growth in urban tourism in Portugal. Although the academic discussion on gentrification has a somehow longer lineage in Portugal (Fernandes, 2011; Malheiros, Carvalho, \& Mendes, 2013), not so long ago and for at least two decades, local political dispute in Porto focused on how to fight urban decay. Porto was seen as a classic example of a "donut"-like city, victim of intense suburbanization processes, bound to leave nothing behind but decadent buildings, old and poor people and stagnant shops.

This turn of fortunes reflects the dramatic change occurring in the city over the last years. Although Porto's downtown had been classified as UNESCO's World Heritage in 1996 and object of public space requalification at the turn of the century, it was only during the last decade that the number of passengers arriving at the city's airport grew

CONTACT Pedro Chamusca pchamusca@letras.up.pt $\Theta$ Centre of Studies in Geography and Spatial Planning, University of Porto/CEGOT, Via Panorâmica, s/n, Porto 4150-564, Portugal 
substantially (by 140 percent between 2007-2016), exceeding five million in 2017 (INE, 2017). High-quality hotels and holiday rental accommodation grew markedly; and during the last five years (2012-17), about four out of ten downtown retail shops went through functional and/or ownership change (Kärrholm, Barata-salgueiro, Soumagne, Fernandes, \& Chamusca,2017) with housing prices almost doubling in the city overall (Confidencial Imobiliario, 2018). After decades of stagnation, these changes triggered fast-paced, private-led building rehabilitation, new business revenue and new types of social, economic and physical pressure in a city of about 230.000 inhabitants within its administrative boundary.

As city users and urban functions changed in and around the city centre, they brought the contested notion of gentrification - broadly defined as a process of urban change through the influx of more affluent residents and/or users (Glass, 1964; Zuk, Bierbaum, Chapple, Gorska, \& Loukaitou-Sideris, 2018) - to the core of local political debate. On the one hand, if it is true that residents started to gradually leave Porto's city centre decades ago - reason why the Mayor's narrative denies a link between urban revival and residential exodus - on the other hand, the city's new international appeal is leading to new forms of displacement as remaining and prospective residents and businesses are priced-out and downtown areas rapidly transform into de facto functional tourism and visitor-driven districts (Cocola-Gant, 2016; Marcuse, 1985).

In line with contemporary debates in gentrification studies (Lees, Shin, \& LópezMorales, 2016), such a state of affairs provides an opportunity to critically rethink what gentrification actually means in Porto, a place that has been somehow at the "borderline" of urban theory (Baptista, 2013; Tulumello, 2016), sitting uneasily in relation to the usual North-South dichotomies. Challenging the view - also latent in the Mayor's assertion - that the notion of gentrification should be abandoned due to its growing lack of analytical grasp (Ghertner, 2015), we contend that there is a need to attune it to accommodate new and variegated forms of urban displacement and homogenization currently emerging around the world (Lees et al., 2016), namely as they unfold in heritage-rich, increasingly (internationally) attractive medium-sized cities in Europe.

\section{Gentrification before gentrification}

To be sure, gentrification as a process of urban change and displacement driven by international elites is far from new in Porto and has been occurring for many centuries, in a somehow cyclical fashion. The city's current physical and social composition may indeed be seen as the result of several waves of foreign-led gentrification - notably driven by British (and other northern European) families linked to port wine trading during the late $18^{\text {th }}$ and $19^{\text {th }}$ centuries (Oliveira, 1973). Those new higher-income, longterm settlers occupied former industrial class and fisherman's neighbourhoods in search of what we would refer today as "amenities" - e.g. proximity to the sea, urban parks and even premises for religious profession (Pinto, Alves, Barbosa, \& Lima, 2017) - bringing novel cosmopolitan atmospheres while triggering new living, consumption and leisure preferences that would endure over time (Fernandes, 1985). Yet, already during this period, international tourists visiting the city described processes of displacement and incongruence as they saw "new trendy boulevards [in places] previously occupied by fishermen (...) where the British built beautiful cottages 
surrounded by symmetrical gardens (...)” (Rattazzi, 1880, p. 313), some locating "just beyond the hovel where the beggars sit at home, [originating] an assemblage of incongruities" (Jackson, 1874, p. 303).

Such a process was largely driven by international yet permanent new settlers, traders and businessmen, whose interests and families endured in the city for the generations to come. They became part of the local social and cultural fabric, gaining roots and taking active part in the city's economic and political life. These features of permanence, participation and local embeddedness are in sharp contrast with the speed, volatility and rotation in Porto's early $21^{\text {st }}$ century "floating" and "transnational" gentrifiers (Sigler \& Wachsmuth, 2015) - namely the growing and unprecedent number of international tourists, exchange students and other short-term visitors in the city. Far from Glass' residential-oriented middle classes, they are in a semi-permanent state of flux, but their short-term (apparent) preferences fuel urban transformation on very wide scale, speed and scope.

\section{Functional gentrification and floating city users}

A key manifestation of the previous is the renewed interest on street shopping as well as on new types of services and uses at downtown's public space. A number of surveys carried out in Porto's city centre every six months during 2012-2017 (Chamusca \& Fernandes, 2016) show major changes within an area where spatially and temporallyspecialized streets and new elitist spaces became coexistent with popular stores that resist, void spaces that persist, hybrid situations and recent neo-traditional or "pseudotypical" establishments specially targeting temporary city users rather than residents. These surveys show a still strong incidence of shops selling products for personal use e.g. clothing, shoes - together with others dedicated to leisure, culture and sports, nonspecialized and home-product shops, but also a large and rapidly growing number of "hipster" cafes, restaurants and accommodation units, and several hybrid shops e.g. personal product shops which are also art galleries and bars/restaurants, shared laundries, shoe-repair shops turning into trolley-repair businesses, among others. Yet, what is most surprising is that this structure results from a rather intense change over just five years, in which almost half of the whole stock of retail and service units suffering some kind of transformation - e.g. opening, closure or re-adjustments on its activity (e.g. linked with ownership or tenancy change).

The aforementioned developments have been hand-in-hand with growing land and real estate prices. The cost of buying/renting a commercial shop steadily increased over the last decade, with prices in the city centre practically doubling over the last five years (Confidencial Imobiliario, 2018). This has evolved with intense changes in the city's property ownership landscape, with anonymous investment funds taking control of prime areas and small-medium investors and entrepreneurs moving away. This has been leading to strong pressure from owners seeking to sell their property to real estate funds, even if it implies dumping traditional retailers to provide space for more tourist accommodation, medium-high classes housing or fashionable shops and restaurants.

Yet, and apart from the speed of change, what is striking in Porto is that little of the aforementioned transformation can be linked to regional growth dynamics - such as the re-urbanization of affluent residents, or the rise of new creative occupations valuing 
urban amenities (e.g. Florida, 2002). Although there is some evidence that new professional occupations and economic activity emerged in the city centre during this period as well, there is little sign or notice of residential return. On the contrary, the number of residents in the city, in general, and in the city centre, in particular, kept declining as in the previous decades (Alves, 2017). Actually, and within the metropolitan area, Porto was still the municipality losing inhabitants at the fastest pace (Pordata, 2017), with population decline primarily driven by (outward) migratory flows. It is true that the recent years show some inversion: the city as a whole gained "net" migrating inhabitants for the first time in many years (388 inhabitants from 2015 to 2016). Yet, quite obviously, this occurrence - while widely celebrated by the city administration - cannot explain on-going transformation and the dynamics of functional displacementreplacement that occurred over the last years.

Tourism is the fundamental driver of rapid functional gentrification in the city, not residential change. Tourist flows, displacement and homogenization dynamics interact with one another through visitors' new (short-term) consumption preferences, in a process previously dubbed as touristification (Gotham, 2005; Sequera \& Nofre, 2018). Although early manifestations of this process in Porto had been noticed before (Fernandes \& Chamusca, 2014), during the last decade the city saw an $88 \%$ increase in the number of hotel establishments, with the lodging capacity increasing 69\%; in 2016, the number of registered hotel guests exceeded 1.6 million, out of which $72 \%$ were foreigners (INE, 2017). This unprecedented inflow is closely related to the rising number of coffee shops and restaurants during 2012-16 in the city centre, as well as to its diversification, quality and price increase (Chamusca \& Fernandes, 2016). Another indicator of tourism's influence in city's gentrification dynamics is the rise of local accommodation listings in digital intermediation platforms such as Airbnb. In less than one year (September 2016-June 2017), the number of Airbnb listings in Porto increased 30\%, counting more than 5.500 active listings in June 2017 (Fernandes, Carvalho, Chamusca, \& Mendes, 2018). Not surprisingly, these listings are highly concentrated in the city centre and their growth locally correlated with the rise of building renewal projects, architectonic "beautification", the installation of global brands and real estate price increases over the last years (Confidencial Imobiliario, 2018).

Beyond tourism, a relevant source of functional gentrification is linked to the influx of post-secondary students - referred to as "studentification" in previous studies of British university towns (Smith, 2005). Yet, the case of Porto highlights new international dimensions in this process. With the diffusion of international student exchange programmes and the homogenisation of graduate and post-graduate education in Europe (linked to the Bologna reform), inward student flows increased substantially. Over the last decade-and-a-half, the number of enrolled international students within the University of Porto only more than tripled, while the number of students in international exchange programmes increased five times (University of Porto, 2017). This influx contributed to sharply increase the demand for temporary housing, leading to a $40 \%$ price increase in this segment during 2015-17 only (Uniplaces, 2017), while their higher purchasing power (vis-à-vis residents) and consumption patterns heightened the demand for new types of services, bars, cafes, nightlife, culture, trendy concepts, etc. The link between international students and gentrification is more so as 
their impacts are disproportionally felt in the city centre and adjacent districts, which concentrate the lion's share of temporary student housing demand and the main references of academic tradition (Uniplaces, 2017).

\section{Conclusions and implications}

Today as in the past, Porto's openness and the international inflow of new people, businesses and preferences are largely shaping the city's urban landscape. In this sense, Porto's Mayor is right to say that the city has always been open, cosmopolitan and "gentrified" by international newcomers. As suggested, and possibly also in other medium-sized, heritage-rich cities like Porto, internationalization, gentrification and urban change often seem to go hand-in-hand, and increasingly so.

Yet, by suggesting that gentrification does not exist in the city, the aforementioned statement seems to conflate residential with functional gentrification, to underestimate their interplay and, hence, to downplay other forms of displacement beyond the direct substitution of former residents for new incoming visitors (Cocola-Gant, Marcuse, 1985). When shops and restaurants become too expensive and targeting non-local audiences, or when rampant rents threaten to push the remaining residents away from city areas, this can hardly be seen as a sign of cosmopolitanism. Moreover, and contrarily to previous "gentrification before gentrification" waves in the city, the challenges of an ever-increasing floating population, the dramatic speed of change and high-priced real estate threatens the city capacity to absorb and mingle richer and poorer, new things and old ones (the built environment, practices, culture), thus impacting in the city's overall diversity, sense of place and identity. At the same time, it threatens leading to tourist, student and "bourgeois-bohemian" monocultures that may severely endanger the city center's overall attractiveness in the medium-run.

Clearly, the drivers and processes behind urban displacement and homogenization in Porto are far from the ones in Glass (1964) seminal work in London or in contemporary accounts of, for example, slum clearing in large African metropolises. ${ }^{1}$ Yet, the case of Porto suggests that the overall notion of gentrification is still pertinent, as long as it allows to bring on-board its nuanced contours and specificities (Lees et al., 2016). In this sense, a better understanding of early $21^{\text {st }}$ century gentrification in Porto must accommodate and take seriously at least two of its close "relatives": touristification and studentification. In this case, gentrification has new transnational drivers (beyond the State or global capital flows), namely internationally mobile high-middle classes in search of new places to visit and/or study.

We would argue, as many others, that a certain degree of gentrification is unavoidable, and even desirable for cities like Porto. As shown, many places considered "authentic" today have been the result of former gentrification processes, led by foreign gentry businessman and their families, and economic and leisure-led activity (Pinto et al., 2017). It is also clear that unlocking the potential of formally abandoned and rundown city centre districts would always require new economic activity and city users, be them permanent residents or floating city users. Yet, and contrarily to other European cities in which similar changes occurred gradually during the last decades and whose size could absorb the impact without significant disruption, what is more problematic 
today in Porto is the sheer scale and the speed of change in city centre neighbourhoods, in which floating city users become the main driver of urban change, to which new "space" has to be made available.

These dynamics raise important normative questions about what urban development should look like. As suggested by the Mayor's statement, one may look into gentrification as a normal city transformation process, as urban places are cultural "palimpsests" that reflect different power balances, inviting to understand the value of each time period on a certain place. Seen in this way, gentrification processes - or their touristification-studentification variants - bring new social and economic value to decaying urban areas, renewing buildings and anticipating consumer preferences, increasing gains in home selling and rental, more taxes and jobs (e.g. Carvalho, van den Berg, Galal, \& Teunisse, 2017). From this angle, as many policy initiatives in Porto demonstrate, it is even to be supported through property tax exceptions; investment attraction campaigns; and business-friendly rehabilitation policies encouraging city beautification operations for tourist and high-end segments with displacement, congestion or waste issues as collateral damage to be remediated through other investments (e.g. social housing outside the city centre) and (tourist) taxation. However, from a critical perspective, gentrification threatens the whole notion of "city", bringing to the fore notions of segregation and spatial injustice, with the most fragile able to live only in places not seen as attractive. From this perspective, the State has the mission to curb the market tendency to expand and reinforce inequality. In Porto, the speed and the markedly different perspectives about what gentrification means and implies (ranging from wide liberalism to radical socialism) have been making policy dialogue and reformist policies difficult to be negotiated and legitimated.

To conclude, and beyond the need to extend the scope of the discussion and policy action, the case of Porto also suggests that the relevance of tourists and visitors as drivers of urban displacement raises new, perhaps more fundamental questions about for whom is local development conceived and how could urban life change in the process. The notion of floating (vs. "temporary") city users intends to capture a new sense of speed, a semi-permanent state of flux and, consequently, lack of local embeddedness and a certain passivity vis-à-vis the city contexts and atmospheres they "consume", as well as the local civic life. Hence, it brings to the fore local democracy issues as the "voting city" is gradually hollowed out by - and yet planned for - floating city users. Moreover, the potential incongruities of such a gentrification mode should lead urban policymakers and elected representatives to reflect on whether such a model of urban development will lead to new conviviality or ghettoization; to cosmopolitanism, indifference or resentment; and whether, paradoxically, the open and international ethos of cities like Porto may become at risk.

\section{Note}

1. We thank one anonymous referee for making this remark. 


\section{Disclosure statement}

No potential conflict of interest was reported by the authors.

\section{Funding}

This work was supported by the Portuguese Foundation for Science and Technology (FCT), through the following grants: UID/GEO/04084/ 2013; PTDC/GES-URB/30551/2017; SFRH/BPD/ $103707 / 2014$.

\section{ORCID}

Luís Carvalho (D) http://orcid.org/0000-0002-7700-4558

Pedro Chamusca (D) http://orcid.org/0000-0001-6921-8057

José Fernandes (D) http://orcid.org/0000-0002-2849-8897

Jorge Pinto (D) http://orcid.org/0000-0002-0195-3853

\section{References}

Alves, Sónia. (2017). Requalificação e gentrificação no centro histórico do Porto Scripta Nova. Revista Electrónica de Geografía y Ciencias Sociales, 21(557), 1-32.

Baptista, Idalina. (2013). The travels of critiques of neoliberalism: Urban experiences from the "Borderlands". Urban Geography, 34(5), 590-611.

Carvalho, Luís, van den Berg, Leo, Galal, Hazem, \& Teunisse, Peter. (2017). Delivering sustainable competitiveness: Revisiting the organising capacity of cities. Abingdon: Routledge.

Chamusca, Pedro, \& Fernandes, José. (2016). A nova vida do centro da cidade do Porto: Metodologias de acompanhamento e avaliação. In Margarida Queiroz, Ana Louro, \& Paulo Maciel (Eds.), O desafio do planeamento e observação territorial nos países Iberoamericanos para o século XXI (pp. 227-234). Lisboa: Universidade de Lisboa.

Cocola-Gant, Agustin. (2016). Holiday rentals: The new gentrification battlefront. Sociological Research Online, 21(3), 1-9.

Confidencial Imobiliario. (2018, February 10). Housing sales market. Retrieved from https:// confidencialimobiliario.com/en/\#indicadores

Fernandes, José. (1985). A Foz: Contributo para o estudo do espaço urbano (Master Thesis in Geography). University of Porto, Porto.

Fernandes, José. (2011). Area-based initiatives and urban dynamics. The case of the Porto city centre. Urban Research \& Practice, 4(3), 285-307.

Fernandes, José, Carvalho, Luís, Chamusca, Pedro, \& Mendes, Thiago. (2018). O Porto e a Airbnb. Porto: Book Cover.

Fernandes, José, \& Chamusca, Pedro. (2014). Urban policies, planning and retail resilience. Cities, 36, 170-177.

Florida, Richard. (2002). The rise of the creative class: And how it's transforming work, leisure, community and everyday life. New York: Perseus Book Group.

Ghertner, David Asher. (2015). Why gentrification theory fails in 'much of the world'. City, 19 (4), 552-563.

Glass, Ruth. (1964). London: Aspects of change. London: MacGibbon and Kee.

Gotham, Kevin Fox. (2005). Tourism gentrification: The case of New Orleans' Vieux Carre (French quarter). Urban Studies, 42(7), 1099-1121.

INE. (2017). Tourism statistics. Lisboa: Instituto Nacional de Estatística.

Jackson, Catherine. (1874). Fair Lusitania. London: Richard Bentley \& Son.

Kärrholm, Mattias, Barata-salgueiro, Teresa, Soumagne, Jean, Fernandes, José, \& Chamusca, Pedro (2017). Time-space complexity and the opening hours of commerce: A study of four 
European cities Revista de Geografia e Ordenamento do Território (GOT), n. ${ }^{\circ} 12$ (dezembro) (pp. 153-177). Centro de Estudos de Geografia e Ordenamento do Território. doi:10.17127/ got/2017.12.007

Lees, Loretta, Shin, Hyun-Bang, \& López-Morales, Ernesto. (2016). Planetary gentrification. Cambridge: Polity Press.

Malheiros, Jorge, Carvalho, Rui, \& Mendes, Luís. (2013). Gentrification, residential ethnicization and the social production of fragmented space in two multi-ethnic neighbourhoods of Lisbon and Bilbao. In Finisterra, XLVIII (Vol. 96, pp. 109-135). CEG, Universidade de Lisboa.

Marcuse, Peter. (1985). Gentrification, abandonment, and displacement: Connections, causes, and policy responses in New York City. Journal of Urban \& Contemporary Law, 28, 195-240.

Oliveira, José Pereira. (1973). O espaço urbano do Porto. Coimbra: Instituto de Alta Cultura.

Pinto, Jorge, Alves, Daniela, Barbosa, Helder, \& Lima, Ricardo. (2017, November). Entre a vida e a morte: O cemitério britânico e o bairro inglês no Porto oitocentista. XI Congresso da Geografia Portuguesa, Porto.

Pordata. (2017, December 20). Population and household statistics. Retrieved from https://www. pordata.pt/Subtema/Municipios/População+Residente-214

Rattazzi, Marie Letízia. (1880). Le Portugal à vol d'oiseau: Portugais et portugaises. Paris: A. Degorce-Cadot.

Sequera, Jorge, \& Nofre, Jordi. (2018). Shaken, not stirred: New debates on touristification and the limits of gentrification. Cities, (online first). doi:10.1080/13604813.2018.1548819

Sigler, Thomas, \& Wachsmuth, David. (2015). Transnational gentrification: Globalisation and neighbourhood change in Panama's Casco Antiguo. Urban Studies, 53(4), 705-722.

Smith, Daren. (2005). 'Studentification': The gentrification factory? In Rowland Atkinson \& Gary Bridge (Eds.), Gentrification in a global context: The new urban colonialism (pp. 72-89). London: Routledge.

Tulumello, Simone. (2016). Reconsidering neoliberal urban planning in times of crisis: Urban regeneration policy in a "dense" space in Lisbon. Urban Geography, 37(1), 117-140.

Uniplaces. (2017, February 10). An analysis of the student rental market in Portugal: Lisbon and Porto. Retrieved from http://portal.uniplaces.com/wp-content/uploads/2017/02/Relatorio_ Mercado_Arrendamento_1Q2017.pdf

University of Porto. (2017). The university in numbers. Retrieved from https://sigarra.up.pt/up/pt/

Zuk, Mirian, Bierbaum, Ariel, Chapple, Karen, Gorska, Karolina, \& Loukaitou-Sideris, Anastasia. (2018). Gentrification, displacement and the role of public investment. Journal of Planning Literature, 33(1), 31-44. 